\title{
Techniques Used by Teachers in Correcting Students' Oral Errors in an Omani Boys School
}

\author{
Ibrahim Mohamed Al-Faki \\ English Language Institute, King Abdul Aziz University, KSA; \\ on Secondment from Wadi El-Neel University, Sudan \\ Ahmed Gumaa Siddiek (Corresponding Author) \\ English Department, P.O. Box 18, Dawadami, Shaqra University, KSA 11911
}

\begin{abstract}
This study aimed to elicit the types of oral corrective feedback that was used by teachers and mostly preferred by students in both cycles of the Basic educational System in Oman. The paper discussed the results of data collected by using three instruments: a teacher's preferences elicitation instrument, a student's preferences elicitation instrument, and a classroom observation checklist. Then the results were processed to test these hypotheses that: Teachers of English at C2 \& PB levels of boys Educational System in Oman use different types of oral correction techniques. It was also hypothesized that there would be a significant difference between these teachers' attitudes about oral corrective feedback and their actual practice. In addition to that, students at $\mathrm{C} 2$ and $\mathrm{PB}$ would expect specific oral corrective feedback approaches from their teachers. The data was processed and all hypotheses were proved to be positive. We made some recommendations, with suggestions for further investigations on the same topic.
\end{abstract}

Index Terms - corrective feedback, error analysis, oral communicative competence

\section{INTRODUCTION}

\section{A. Statement of the Problem}

The idea behind this survey stems from the fact that, as experienced teachers of English in the field, we have noticed that some teachers have poor teaching performance due to lack of teaching techniques or due to lack of judging timely interference to modify learners' oral error during classes. Having this in mind, we have decided to share our experience with these teachers to provide them with some suggestions that might improve their interfering techniques, to improve oral performance and attain successful communication.

\section{B. Research Hypotheses:}

We aim to examine these hypotheses that:

1. Teachers of English at C2\& PB levels of boys Educational System in Oman use different types of oral correction techniques.

2. There is a significant difference between these teachers' attitudes towards oral corrective feedback and their actual practice.

3. Students at $\mathrm{C} 2$ and $\mathrm{PB}$ of the Boys Educational System in Oman expect specific oral corrective feedback approaches from their teachers.

\section{Objective of the Study:}

English Language teachers can use the techniques of oral correction to boost students learning. Therefore, in conducting this is study we are trying to:

1. To find out if the male English Language teachers in Oman use different types of oral correction techniques at $\mathrm{C} 2$ and PB levels.

2. To compare the English teachers' attitudes towards corrective feedback with their actual performance in their classes.

3. To realize the types of oral corrective feedback techniques that students prefer more, to be used by their teachers to support their learning at each educational level at the Post-Basic (PB) in the Omani education context.

\section{The Significance of the Study:}

This study is intended to investigate error correction techniques used by EFL teachers, so it is mainly targeting English language teachers in the field. We hope to provide our fellow teachers with some ideas from our own experience in the field. The findings of the survey will also be of great use to course and textbook designers, as it will give some insight to embed some ideas in their work. This will benefit both EFL teachers and learners. 


\section{RELATED STUDIES}

Oral corrective feedback plays a significant role in the learning process. Relevant literature reveals that there is " $\ldots$ a growing consensus among the majority of researchers concerning the significance of the role played by negative evidence (corrective feedback) in the process of SLA". El Tatawy (2002), Ellis, Basturkmen, \& Loewen (2001), Loewen (2004) and Lyster \& Ranta (1997) are with the idea that the role played by oral corrective feedback in the English classroom cannot be ignored. There are a number of previous studies that dealt with the oral corrective feedback, its types, the relationship between teachers' attitudes and practices, and the preferences of students.

One of the earliest international studies in this field was conducted by Chaudron (1977). In his study, Chaudron examined the effect of corrective feedback on oral production of students. He investigated the effect of different types of oral corrective feedback provided to French immersion students by their teachers. Chaudron observed that "repetition with emphasis" was more effective than the other types of oral corrective feedback, as it led to more immediate reformulation on the part of students (Russell \& Spada, 2006).

A number of studies then examined the use of different types of oral corrective feedback. For example, Doughty (1994) in his observation of different types of oral corrective feedback used by different teachers, found that "clarification requests", "repetition" and "recasts" were the most frequently used types (Russell \& Spada, 2006).

One of the important studies in this area was the one conducted by Lyster and Ranta in (1997). In their study, they investigated the use of oral corrective feedback by teachers in grades 4 and 5 French immersion classrooms. They identified six feedback types of oral corrective feedback used by teachers: explicit correction, recast, clarification requests, metalinguistic feedback, elicitation, and repetition. They found that recasts were the most common type of corrective feedback used by the teachers.

From that time onwards, a number of researchers, like this research, used Lyster and Ranta's (1997) model of oral corrective feedback for analyzing the types of oral corrective feedback used by teachers in different parts of the world. For example, Lin (2009), investigated the types of oral corrective feedback that ESL teachers used in low, intermediate, and advanced level speaking classrooms using Lyster and Ranta's (1997) model. He involved participants from ESL program at a Southern California State University. The results showed that lower level students were corrected by their teachers more than the higher level students and that recasts were the most frequent used types.

Panova and Lyster (2002) also conducted an observational study in which they involved some early-intermediate adult ESL classrooms in Quebec. They also found that recasts were the most frequent type of oral corrective feedback used by the teachers.

At the regional level, Tabatabaei and Banitalebi (2011) investigated the most frequent type of oral corrective feedback techniques used by L2 Iranian teachers in L2 reading comprehension classes in an Iranian language institute. They focused on explicit correction, recast, clarification request, metalinguistic feedback, elicitation, and repetition. They found that explicit correction was the most frequent feedback technique used by teachers and elicitation was the second one ( $49 \%$ \& 19\%, respectively). They applied a Chi-square test and the results showed that there was a significant difference among the frequencies of the feedback types in favour of explicit correction.

To the best knowledge of the researchers' knowledge, no one has investigated the teachers' attitudes and their actual practice about oral corrective feedback in the Arab region. The closest study to this area was conducted by Kartchava (2006) in which the researcher investigated novice ESL teachers' beliefs about oral corrective feedback and their practice. The results indicated both consistency and inconsistency in the relationship. The 99 teachers-in-training were consistent in the type of oral corrective feedback they chose to use in the classrooms, but they corrected fewer errors in their classrooms than they said they would.

Finally, and as stated previously, there are some studies that dealt with the issue of students' preferences regarding oral corrective feedback types. Ancker (2000) in his survey examined teachers' and students' expectations of error correction. The results of his study go, line by line, with Nunan (1993) one in which he examines the relationship between the attitudes of students and teachers to a range of activities.

\section{Methodology}

\section{A. Population and Sample}

The population of this study is 326 male teachers in Muscat Governorate who teach at boys schools, from whom the oral corrective feedback was provided as (30) English language teachers were investigated. The population is divided into two stratum, (200) expatriate teachers and (126) Omani teachers. Stratified random selection was made to select (15) teachers from C2, (6 Omani \& 9 expatriates) and (15) teachers from PB schools, (6 Omani \& 9 expatriates). Six classes from two states were involved in this study including a class from each of Grades 7, 8, 9, 10, 11, and 12. From each class (25) students are selected to represent the students population which makes total of (150) students.

\section{B. Instruments}

These three instruments were developed based on the related literature and they are of the qualitative type.

\section{The Observation Checklist}


The term 'observation' is used as a research tool that offers researchers an opportunity to gather 'live' data from "naturally occurring situations" where the researcher can actually look directly at what is happening in situation rather than depending on second-hand data source, (Cohen et al 2007). Based on that, the researchers designed the observation checklist to record down oral corrective feedback types used by the target teachers at the two levels of the boys schooling - C2 and PB.

\section{The Teacher's Preference Elicitation Questionnaire}

The Teacher's Preference Elicitation Questionnaire was adapted from Michael (2007 to elicit the types of oral corrective feedback that teachers prefer to use to correct their students' errors (see appendix A).

\section{E. The Student's Preference Elicitation Questionnaire}

The students' Preference Elicitation Questionnaire was adapted from Michael (2007), to elicit the types of oral corrective feedback techniques that students preferred their teachers to use. Similarly like the Teachers' Preference Elicitation Instrument, Students' preference elicitation questionnaire elicits the students' preferences through the use of a description of a teaching situation followed by several teacher responses.

\section{F. Validity and Reliability of the Classroom Observation Checklist}

After the classroom observation checklist had been developed, it was given to a group of senior English Language teachers and ESL lecturers at Nizwa University jury panel to establish its validity. The jury members were asked to judge whether the included items were clear and relevant to the topic under investigation or not. They were also requested to propose any modifications or changes to the instrument. Some of them suggested that the statements which represent the definitions of the types of oral corrective feedback should be shortened by omitting some unnecessary words (see appendix A). The instrument had a general internal consistency of 0.902 which is excellent according to Cronbach's alpha description.

\section{G. Validity and Reliability of the TS'P.E.Q.}

To determine the reliability of the questionnaire, it was piloted by (30) teachers from Muscat Governorate. The results showed that the teachers' preference elicitation questionnaire had an internal consistency of (0.891) which represented a good degree of consistency according to the description of Cronbach's alpha. Overall, the piloting results revealed that the instrument was clear, valid and relevant to the topic.

\section{H. Validity and Reliability of the Ss' P.E.Q.}

The reliability of the questionnaire was piloted by (105) male students. Of them, (50) were students from grades nine, (20) students were from grade ten, (20) students were from grade (11) and (15) were from grade (12). The results showed that the students' preference elicitation questionnaire had an internal consistency of $(0.75)$ which represented an acceptable degree of consistency according to Cronbach's alpha. Usually a reliability coefficient of (0.70) and above is acceptable (Nunnally, 1978). As for the previous instruments, the piloting results revealed that this instrument was clear, valid and relevant to the topic.

\section{RESULTS AND DiSCUSSION}

\section{A. Introduction}

Now we discuss the results of data from the three instruments: the teacher's preferences elicitation instrument, the student's preferences elicitation instrument, and the classroom observation checklist. The results are discussed in the same order according to the research hypotheses that:

1. Teachers of English at C2\& PB levels of boys Educational System in Oman use different types of oral correction techniques.

2. There is a significant difference between these teachers' attitudes about oral corrective feedback and their actual practice.

3. Students at $\mathrm{C} 2$ and $\mathrm{PB}$ of the Boys Educational System in Oman expect specific oral corrective feedback approaches from their teachers.

\section{B. Oral Corrective Feedback Types Used by C2 and PB English Teachers}

To check the first hypothesis, which seek find the types of oral corrective feedback used by English teachers in $\mathrm{C} 2$ and PB schools, the means and standard deviations of the number of times the different types of oral corrective feedback used by the 15 teachers in each cycle were calculated. For the purpose of data analysis of mean values, we used the following norms:

Mean values (4.5 or more) = (Highly used/ highest usage/ most frequently used/ the most used/ most commonly used) Mean values (3-4.49) $=($ Moderately used/ of a moderate use $)$

Mean values (2.99 or less) $=$ (Low frequency of use/ of very low usage/ lowest use) 
First of all, Table (1) summarizes the grand mean number of times of usage and the standard deviations for all types of oral corrective feedback the 15 teachers in each cycle used to correct their students' spoken errors.

TABLE (1)

DESCRIPTIVE STATISTICS (MEANS NUMBER OF TIMES \& STANDARD DEVIATIONS) FOR THE TWO CYCLES OF THE BASIC EDUCATIONAL SYSTEM

\begin{tabular}{|l|l|l|}
\hline Cycle & Grand Mean Number of Times & Std. Deviation \\
\hline Cycle 2 & 38.64 & 2.135 \\
\hline Post Basic & 34.74 & 2.789 \\
\hline Average & $\mathbf{3 6 . 6 9}$ & $\mathbf{2 . 4 6}$ \\
\hline
\end{tabular}

Table (1) shows that the least users of different types of oral corrective feedback among the two groups of teachers were the PB teachers with a mean number of (34.74) and standard deviation of (2.8). On the other hand, the table shows that $\mathrm{C} 2$ teachers use different types of corrective feedback with mean number of (38.64) and a standard deviation of (2.14). Finally, the table shows that the average use of different types of oral corrective feedback among the teachers of the two cycles was (36.7).

Tables (2 and 3) present the mean number of times and standard deviations for different types of oral corrective feedback used by C2 and PB teachers to correct their students' spoken errors.

TABLE (2)

MEAN NUMBER OF TIMES AND STANDARD DEVIATION FOR THE TYPES OF ORAL CORRECTIVE FEEDBACK USED B Y C2 TEACHERS TO CORRECT THEIR STUDENTS' SPOKEN ERRORS

\begin{tabular}{|l|l|l|l|l|}
\hline OCF Technique & N & $\begin{array}{l}\text { Total Number of Times } \\
\text { Each Type Used }\end{array}$ & Means & Std. Deviation \\
\hline Recast & 15 & 134 & 8.93 & 2.086 \\
\hline Elicitation & 15 & 77 & 5.13 & 1.995 \\
\hline Questioning (Peer Correction) & 15 & 69 & 4.60 & 2.444 \\
\hline Repetition & 15 & 56 & 3.73 & 1.870 \\
\hline Metalingustic Feedback & 15 & 53 & 3.53 & 1.727 \\
\hline Clarification Request & 15 & 50 & 3.33 & 1.718 \\
\hline Questioning (Self Correction) & 15 & 47 & 3.13 & 2.295 \\
\hline Explicit Correction & 15 & 47 & 3.13 & 1.407 \\
\hline Denial & 15 & 35 & 2.33 & 1.718 \\
\hline Ignorance & 15 & 12 & .80 & .414 \\
\hline Average & - & - & $\mathbf{3 . 8 6 4}$ & $\mathbf{1 . 7 6 7}$ \\
\hline
\end{tabular}

Table (2) shows that, Cycle 2 teachers used all types of oral corrective feedback with a grand mean of (3.86) and a standard deviation of (1.77). It also shows that recast, elicitation, and questioning (Peer-correction) were reported to be the most frequently used types of oral corrective feedback in C2. Recast had the highest usage as it had a mean of (8.93) and a standard deviation of (2.09). Elicitation and questioning (Peer-correction) can also be considered as types that were highly used as they had means of (5.13) \& (4.60) and standard deviations of (2.00) \& (2.44), respectively. Cycle 2 teachers might use these techniques more to increase the level of participation among students as well as to encourage cooperative learning without explicitly correcting their students' errors. However, there is a big gap between the use of recast and other types of oral corrective feedback types. This could clearly indicate the preference of one type over other types.

Table (2) also shows that repetition, metalingustic feedback, clarification request, questioning (self-correction) and explicit correction were the five moderately used types of oral corrective feedback by $\mathrm{C} 2$ teachers as they had means between 3 and 4.49 and standard deviations of (1.870), (1.727), (1.718), 2.295) \& (1.407) respectively. The use of these types might indicate that $\mathrm{C} 2$ teachers started to feel that their students were more capable at this stage to cope with such techniques which need a certain level of language proficiency. These findings are inconsistent with previous research. In their studies, Lyster \& Ranta (1997), Panova \& Lyster (2002), and Sheen (2004) all found that metalinguistic feedback, repetition, and clarification request were not often used by teachers.

Finally, Table (2) reveals that Denial and ignorance were of a very low usage as they had a mean of (2.33) \& (.80) and a standard deviation of (1.72) \& (.41) respectively. This is in line with the studies of Lyster \& Ranta (1997) and Panova and Lyster (2002). These researchers found that denial and ignorance were rarely used by teachers. This might indicate that teachers were trying to use other forms of oral corrective feedback to create a form of interaction in the classroom. 
TABLE (3)

MEAN NUMBER OF TIMES AND STANDARD DEVIATIONS OF THE TYPES OF ORAL CORRECTIVE FEEDBACK USED BY PB TEACHERS TO CORRECT THEIR STUDENTS' SPOKEN ERRORS

\begin{tabular}{|l|l|l|l|l|}
\hline OCF Technique Type & N & Total Number of Times Each Type Used & Means & Std. Deviation \\
\hline Recast & 15 & 153 & 10.20 & 2.145 \\
\hline Elicitation & 15 & 85 & 5.67 & 1.952 \\
\hline Questioning (Peer Correction) & 15 & 69 & 4.60 & 1.502 \\
\hline Denial & 15 & 49 & 3.27 & .884 \\
\hline Clarification Request & 15 & 43 & 2.87 & .834 \\
\hline Questioning (Self Correction) & 15 & 33 & 2.20 & .862 \\
\hline Repetition & 15 & 27 & 1.80 & .676 \\
\hline Metalingustic Feedback & 15 & 26 & 1.73 & .704 \\
\hline Ignorance & 15 & 25 & 1.67 & .617 \\
\hline Explicit Correction & 15 & 11 & 73 & .458 \\
\hline Average & - & - & $\mathbf{3 . 4 7 4}$ & $\mathbf{1 . 0 6 3 4}$ \\
\hline
\end{tabular}

As Table (3) reveals, PB teachers used all types of oral corrective feedback with a grand mean of (3.50) and a standard deviation of (1.06). Recast, elicitation and questioning (Peer-correction) were reported to be the most used types of oral corrective feedback in PB. As in C2, Recast had the highest usage as it had a mean of (10.20) and a standard deviation of (2.16). Again, we can notice the big gap between the use of recast and other techniques.

The highest usage of recast by PB teachers might be attributed to their desire to save time and at the same time encourage slow learners to continue speaking without explicitly correcting their errors. This finding is similar to the study of Lyster and Ranta (1997) who found that the teachers in their study provided corrective feedback using recasts over half of the time $(55 \%)$.

The findings of Pica and Long (1986) also support this finding as they reported that recasts were used over other types of oral corrective feedback.

Elicitation and questioning (Peer-correction) were highly used as they had means of (5.67) \& (4.60) and standard deviations of (1.952) \& (1.502), respectively. This could be attributed to PB teachers' desire to increase students' participation by using elicitation and questioning (peer-correction). The table showed that denial is used moderately by PB teachers. This could be attributed to the teachers' desire to give more chances for their students to negotiate meaning by using the previous two types.

Table (3) also shows that clarification request, questioning (self-correction), repetition, metalinguistic feedback, ignorance and explicit correction were the six least used types of oral corrective feedback as they had means of (2.87), (2.20), (1.80) (1.73), (1.67)\& (.73) and standard deviations of (0.83), (0.86), (0.68), (0.70), (0.62)\& (.46), respectively. As the table shows, explicit correction has the lowest usage in this category. The low usage of explicit correction could be attributed to PB teachers' desire not to spoon-feed their students, especially at this stage of learning where teachers are supposed to encourage their students to be more independent learners.

Overall, Tables (2) and (3) give indications that English teachers in C2 and PB levels use all types of oral corrective feedback in varying degrees. Many previous studies support this finding. Studies like those of Pica and Long (1986) and Lyster and Ranta (1997), all reported the use of recasts, clarification request, metalinguistic feedback, elicitation, repetition and explicit correction to some degree.

The tables also show that there were least cases in $\mathrm{C} 2$ where the students committed errors and their teachers did not provide them with any type of oral corrective feedback compared to (PB). While there were least cases in PB where the students committed errors and their teachers did not provide them with any explicit correction.

In addition to that, Tables (2) and (3) also indicate that all teachers in the two cycles of the Basic Education moderately used repetition and reported to have a very low usage of explicit correction, denial and ignorance with varying degrees.

The teachers who participated in this study provided the researcher with some comments about this result. One teacher said: "Not all teachers believe that repetition is the best way for oral correction, they keep adjusting their techniques according to the effect they see on their students' performance." Surprisingly, one teacher disagreed with him as he stated that: "Repetition is a good technique because it helps students notice their errors not like explicit correction which gives them the correct version on a plate."

On the other hand, Tables (2) and (3) also show that C2 and PB teachers may use oral corrective feedback for a number of reasons such as being less sensitive about students' feelings because they are dealing more with grown-ups.

Another reason could be having students who have reached a level of language proficiency that allows them to be more independent in self-correction even with little hints.

In addition, denial was reported to be of the moderate use type of oral corrective feedback in PB, whereas it was reported to be of a very low use in $\mathrm{C} 2$. The teachers who participated in this study provided the researcher with the following interesting comments about this result.

One teacher said: "Maybe in the stage of PB, teachers believe that students have the readiness to discover or search their own errors and that denial will stimulate students to find answers which results in good knowledge obtained by such strategy."

Another teacher said: "Students in PB have more awareness and can accept this form of error-correction." 
A third teacher who agreed with the previous two added: "Unlike C2, PB students are capable enough to be able to identify their errors using their prior knowledge. Possibly, students at this level are more autonomous, i.e. they are used to find things for themselves."

One of the teachers mentioned that: "Students are more mature in PB and they are used to denial as a way of giving oral correction, especially when they study Science and Math.”. Finally, one teacher added an interesting point. He said: "I guess in C2 the errors committed by the students are obviously more and teachers do not want to frustrate them. On the other hand, in PB the mistakes generally are less and teachers state it directly."

Finally, the two tables give indications that clarification request and metalinguistic feedback were moderately used by PB teachers and of low use by $\mathrm{C} 2$. The teachers who participated in this study made some comments about this result.

One teacher said: "These two strategies require high thinking abilities and a kind of analysis which is compatible with students in PB compared to C2."

Another teacher added: "This indicates their moderate level of language proficiency. In addition, the type of questions asked could be referential where the answer is not necessarily known by the teacher."

Finally, an interesting comment was stated by one of the teachers. He said: "Clarification request is used in C2 and PB because in these stages students need to give longer answers. In case the students are not competent enough, teachers sometimes ask for clarification or are forced to give metalinguistic feedback."

Overall, the previous results give us indications that English teachers in C2 use oral corrective feedback more than PB teachers. This could be attributed to a number of factors like: (1) the very heavy curriculum that C2 teachers use which forces them to speed up without paying the necessary attention to many important issues such as focused oral corrective feedback, and

(2) C2 and PB teachers might be more able to use a wider range of different types and amounts of oral feedback techniques as they deal with students who have better language abilities.

The teachers who participated in this study provided the researcher with some interesting comments about this result. One teacher said: "This is really surprising. It should be the opposite. However, this may show that that they are very much concerned with time; they want to save time."

Another teacher said: "This maybe because C2 and PB students have more awareness about error-correction."

A third teacher stated: "Because students in C2 and PB are grown-ups and can communicate more with the teacher."

Finally, an interesting comment was added by a teacher. He said: "I think teachers in C2 and PB use these strategies because their students have reached to such level that they can use high analytical skills to correct their own errors or to be given such little hints to reach the correct answer."

\section{The Relationship between Teachers' Attitudes towards Oral Corrective Feedback and their Actual Practice}

To response to question two, which seeks to find the relationship between the attitudes of the teachers and their actual practice, the correlation between the two variables was calculated using Pearson's correlation coefficient.

Table (4) shows the detailed calculation for correlation of the number of times each oral correction technique used in the classroom and the total number of times each of these techniques elicited from the target teachers.

TABLE 4

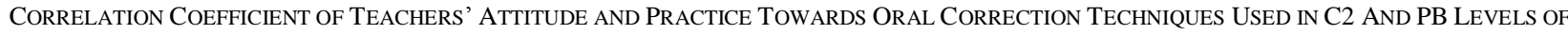
BASIC EDUCATIONAL SYSTEM

\begin{tabular}{|l|l|}
\hline KEY & Result Details \& Calculation \\
X: X VALUES & $\sum(\mathrm{X}-\mathrm{Mx})^{2}=\mathrm{SSx}=39664.9$ \\
Y: Y VALUES & $\sum(\mathrm{Y}-\mathrm{My})^{2}=\mathrm{SSy}=24901.6$ \\
Mx: Mean of X Values & $\mathrm{X}$ and $\mathrm{Y}$ Combined \\
My: Mean of Y values & $\mathrm{N}=10$ \\
$\mathrm{X}-\mathrm{Mx} \& \mathrm{Y}-\mathrm{My}:$ Deviation scores & $\sum(\mathrm{X}-\mathrm{Mx})(\mathrm{Y}-\mathrm{My})=-8022.2$ \\
$(\mathrm{X}-\mathrm{My})^{2}: \&(\mathrm{Y}-\mathrm{My})^{2}$ : Deviation Squired & $\mathrm{R}$ Calculation \\
$(\mathrm{X}-\mathrm{Mx})(\mathrm{Y}-\mathrm{My}):$ Product of Deviation & $\mathrm{r}=\sum((\mathrm{X}-\mathrm{My})(\mathrm{Y}-\mathrm{Mx})) / \sqrt{ }((\mathrm{SSx})(\mathrm{SSy}))$ \\
Scores & $\mathrm{r}=-8022.2 / \sqrt{((39664.9)(24901.6))=-0.26}$ \\
& Meta Numerics $($ cross-check $)$ \\
& $\mathrm{r}=-0.26$ \\
\hline
\end{tabular}

The results showed that there was no statistical significant correlation between teachers' attitudes about oral corrective feedback and their actual practice $[r=$ minus 0.26$]$. This means that there was no relationship between English language teachers' attitudes about oral corrective feedback and their actual practices.

Teachers usually plan their lessons in advance but faced with many factors that hinder proper implementation of this plan. These factors could be attributed to the followings: time constraints under which the teachers work, heavy curriculum which force teachers to work under pressure, and complicated tasks which are far above the actual level of the majority of the students.

According to The English Language Curriculum Framework (2011), which was produced by the Ministry of Education in the Sultanate of Oman, English teachers need to cover a number of lessons in each semester which usually consists of four months. The number of lessons that should be taught in each semester range between (60-75 lessons) for C2 and (72-96 lessons) for PB level. 
The teachers who participated in this study provided us with some comments about this result. One teacher stated the following comment: "It is the case for most teachers not to have enough time to apply proper techniques."

Another teacher said: "Time constraints, heavy curriculum, and complicated tasks all are factors that can force the teacher to work against his attitudes and beliefs."

Another teacher added: "This might due to the huge number of things that teachers need to control in their classrooms. So sometimes the circumstances do not let some teachers to apply what they think appropriate."

Another teacher complained that: "Many teachers are not satisfied with the current curriculum which directs them to behave differently from what they really think." Finally, a very interesting point was added by one of the teachers who criticized: "This means they are not reflective teacher. Otherwise they would have questioned their practice and would have modified it accordingly. They teach according to their tacit beliefs."

This finding is consistent with many previous studies which show mismatches between teachers' views and practices (Cathcart\& Olsen, 1976; Karavas-Doukas, 1996; Katayama, 2006; McCargar, 1993; Nunan, 1988; Oladejo, 1993; Schulz, 1996, 2001).

\section{C2 and PB Students Preferred Types of Oral Corrective Feedback}

To answer question three, about the types of oral corrective feedback preferred by students in C2, and PB, the means and standard deviations of the number of usage of the types of oral corrective feedback preferred by $\mathrm{C} 2$ and PB students are calculated. The results are presented in Tables $(5 \& 6)$. The students, in the preferences elicitation instrument (See Appendix A), were requested to rate how well they think each of the listed teacher response helps them understand that they have made an error and would help them improve their English using the following scale: $3=$ very helpful, $2=$ helpful, $1=$ not helpful, and $0=$ not helpful at all. For the purpose of data analysis of mean values, the researcher decided to use the following norms:

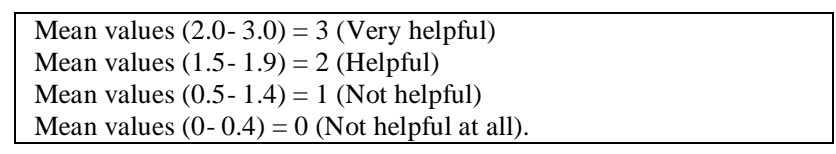

TABLE (5)

DESCRIPTIVE STATISTICS (MEANS\& STANDARD DEVIATIONS) OF THE TyPES OF ORAL CORRECTIVE FEEDBACK PREFERRED By C2 STUDENTS

\begin{tabular}{|l|l|l|l|l|}
\hline OCF Technique & $\mathbf{N}$ & Total Number of Time Each Type Used & Mean & Std. Deviation \\
\hline Metalingustic Feedback & 100 & 227 & 2.27 & .908 \\
\hline Explicit Correction & 100 & 219 & 2.19 & .775 \\
\hline Recast & 100 & 191 & 1.91 & .767 \\
\hline Denial & 100 & 166 & 1.66 & .924 \\
\hline Questioning (Peer Correction) & 100 & 165 & 1.65 & .978 \\
\hline Questioning (Self Correction) & 100 & 156 & 1.56 & 1.104 \\
\hline Elicitation & 100 & 154 & 1.54 & 1.968 \\
\hline Repetition & 100 & 151 & 1.51 & 1.35 \\
\hline Clarification Request & 100 & 135 & 1.029 & 1.92 \\
\hline Ignorance & 100 & 92 & $\mathbf{1 . 6 6}$ & $\mathbf{1 . 1 7}$ \\
\hline Average & - & - & & \\
\hline
\end{tabular}

Table (5) reveals that metalingustic feedback and explicit correction were "very helpful'" types by C2 students. The table also shows that recast, denial, questioning (peer correction), questioning (self correction), elicitation and repetition were all considered 'helpful'" types of oral corrective feedback by C2 students as their mean value range between (1.5) and (1.9). Metalingustic feedback and explicit correction were reported to be the types of oral feedback most preferred by C2 students with mean values of (2.27) and (2.19) and standard deviation of (0.91) \& (0.78), respectively.

This finding is similar to a study conducted by Smith (2010). In his study, which involves 76 adult ESL students who were members of adults ESL programmes, he investigated the preference of these learners in error correction. He found that metalingustic feedback and explicit correction were the most preferred types of feedback.

On the other hand, the table shows that clarification request and ignorance were considered as the only types of oral corrective feedback that are "not helpful" with a mean value of (1.35) \& (0.92) and a standard deviation of (1.03) \& (1.07) respectively. This finding is inconsistent with (Smith's 2010) study in which clarification request was the third most preferred type of oral corrective feedback after metalinguistic feedback and explicit correction. Table (6) presents the types of oral corrective feedback that are preferred by PB students. 
TABLE (6)

DESCRIPTIVE STATISTICS (MEANS \& STANDARD DEVIATIONS) OF THE TYPES OF ORAL CORRECTIVE FEEDBACK PREFERRED BY PB STUDENTS

\begin{tabular}{|l|l|l|l|l|}
\hline OCF Technique & N & Total Number of Times Each Type Used & Mean & Std. Deviation \\
\hline Repetition & 50 & 132 & 2.64 & .631 \\
\hline Metalingustic Feedback & 50 & 130 & 2.60 & .728 \\
\hline Denial & 50 & 110 & 2.20 & .833 \\
\hline Explicit Correction & 50 & 100 & 2.00 & 1.178 \\
\hline Elicitation & 50 & 79 & 1.58 & 1.144 \\
\hline Clarification Request & 50 & 72 & 1.44 & 1.110 \\
\hline Questioning (Peer Correction) & 50 & 70 & 1.40 & 1.143 \\
\hline Questioning (Self Correction & 50 & 68 & 1.36 & 1.174 \\
\hline Recast & 50 & 67 & 1.34 & .872 \\
\hline Ignorance & 50 & 35 & .70 & 1.015 \\
\hline Average & - & - & $\mathbf{1 . 5 3}$ & $\mathbf{9 8 3}$ \\
\hline
\end{tabular}

Table (6) reveals that PB students considered repetition, metalingustic feedback, denial and explicit correction as the types of oral corrective feedback that are "very helpful"' as they had mean values of (2.64), (2.60), (2.20) \& (2.00) and standard deviation of $(0.63),(0.73),(.83) \&(1.18)$ respectively.

The table also shows that elicitation alone was seen as 'helpful' type of oral corrective feedback by PB students with a mean value of (1.58). On the other hand, the table shows that clarification request, questioning (peer and self correction), and recast were considered as types of oral corrective feedback that are "not helpful' with mean values of (1.44), (1.40), (1.36) \& (1.34) and standard deviation of (1.11), (1.14), (1.17) \& (0.87) respectively.

Moreover, the table shows that ignorance was considered as "not helpful at all" with a mean value of (0.70) and standard deviation of (1.02). This is supported by the study conducted by Sengupta (1998) in which the students of the study expressed their preferences to be told the correct version by the teacher.

One of the students in (Sengupta's:1998) study stated; "The teacher must tell me" indicating his preference of receiving types of oral corrective feedback like explicit correction, metalinguistic feedback, repetition, and denial. Roskams (1999) also reports a similar finding and suggests that "teachers should probably supplement peer feedback with some kind of teacher feedback" ( $p, 83)$. A possible reason why PB students did not perceive these types as helpful types of oral corrective feedback could be, as Ellis (2009) writes, because "students typically prefer the teacher to do the correction for them" $(\mathrm{p}, 7)$.

\section{Summary, CONCLUSIONS AND RECOMMENDATIONS}

\section{A. Summary of the Study}

The purpose of the study was to examine the types of oral corrective feedback that English teachers use at Cycle2 and Post Basic levels of boys schooling in Oman. It also aimed to compare those English teachers' attitudes towards oral corrective feedback and their actual performance in their classrooms. Finally, it aimed to survey the types of oral corrective feedback techniques that $\mathrm{C} 2$ and PB students prefer to be used by their teachers to support their learning. More specifically the study aimed at checking the following hypotheses:

1. Teachers of English at C2\& PB levels of boys Educational System in Oman use different types of oral correction techniques.

2. There is a significant difference between these teachers' attitudes about oral corrective feedback and their actual practice.

3. Students at $\mathrm{C} 2$ and $\mathrm{PB}$ of the Boys Educational System in Oman expect specific oral corrective feedback approaches from their teachers.

\section{B. Summary of Findings}

The findings of the study can be summarized as follows:

1. English teachers in $\mathrm{C} 2$ and PB of the boys' educational system in Oman use all known types of oral corrective feedback in varying degrees. Recast, elicitation, and questioning (Peer-correction) were the most frequently used types of oral corrective feedback in C2 and PB. Recast had the highest usage in C2 and PB.

2. There are some similarities as well as some differences between teachers regarding their usage of different types of oral corrective feedback, in the two cycles of the Basic Educational System.

3. Teachers in $\mathrm{C} 2$ moderately used repetition, metalinguistic feedback, clarification request, questioning (selfcorrection) and explicit correction and reported to have a very low usage of these in PB.

4. Denial was reported to be of moderate use types of oral corrective feedback in PB, whereas it was reported to be very moderately used in $\mathrm{C} 2$.

5. Like metalinguistic feedback, clarification request was reported of moderate use in C2 and of a very low frequency in $\mathrm{PB}$.

6. There is no significant relationship between English teachers' attitudes towards oral corrective feedback and their actual practice. 
7. There is no significant relationship between English language teachers' attitudes towards oral corrective feedback and their actual practices.

8. English teachers mostly use recast, elicitation, and questioning (Peer-correction) in the two cycles of the Basic Educational System, whereas C2 students prefer metalingustic feedback, explicit correction, recast, denial, questioning (peer \& self-correction), elicitation and repetition. While PB students preferred types of oral corrective feedback were repetition, metalingustic feedback, denial, explicit correction and elicitation. Among them repetition and metalingustic feedback were the most preferred types.

9. By comparing the two results, it can be seen that $\mathrm{C} 2$ teachers use recast, elicitation and questioning (peercorrection) in accordance to their students expectation. However, elicitation is the only common item between the two when we come to PB teachers.

\section{Recommendations}

Based on the results of this study, we can recommend the following:

1. As this study revealed that recast had the highest usage by $\mathrm{C} 2$ and PB teachers among other types of oral corrective feedback, it is suggested that C2 \& PB teachers make more use of other types of oral corrective feedback. Lyster (1998a) and Panova \& Lyster (2002) stress that because recast is an implicit type of oral corrective technique, it might pass unnoticed especially by less advanced students. Lyster and Ranta (1997) add that using elicitation, metalinguistic feedback, clarification request, and repetition encourage students more actively to draw on what they already know.

2. This study revealed that there is no significant relationship between English teachers' attitudes about oral corrective feedback and their actual practice. Schulz (2001) discusses the importance of teacher education programs and their impact on forming teachers' perceptions of effective error correction. He suggests that there is a need for research on what information is being disseminated to students in teacher education programs about corrective feedback.

\section{Suggestions for Further Research}

According to Lyster \& Ranta (1997, 49), student's uptake is "a student utterance that immediately follows the teacher's feedback and that constitutes a reaction in some way to the teacher's intention to draw attention to some aspects of the student's initial utterance". Such a study will, hopefully, let us learn more about how students respond to their teachers' oral corrective feedback and will uncover the types of oral corrective feedback which are more effective in helping students improve their English Language. This study can be replicated in other similar environments in the Arab region by using the same tools to see the degree of agreements of the teachers' and students' attitudes towards corrective feedback strategy in ELT. 


\section{Appendix (A). Classroom Observation Checklist for Oral Corrective Feedback Types}

Types of Oral Corrective Feedback Preferences Elicitation Instrument (Teachers) Types of Oral Corrective Feedback Preferences Elicitation Instrument (Students)

Follow-up Questionnaire (Teachers)

\section{Classroom Observation Checklist for Oral Corrective Feedback Types}

School-------------------------- Teacher ------------------------Grade/Class--------------------

Language focus of the lesson: ----------------Date \& Session No:

\begin{tabular}{|c|c|c|c|c|c|}
\hline No & OCF Type & Definition & Example & $\begin{array}{l}\text { Number of Times } \\
\text { Used by Teacher }\end{array}$ & Comment \\
\hline 01 & Recast & $\begin{array}{l}\text { The teacher repeats } \\
\text { what the learner has } \\
\text { said replacing the } \\
\text { error. }\end{array}$ & $\begin{array}{l}\text { S: Were you surprising by anything in the } \\
\text { article? (error-grammatical) } \\
\mathrm{T}: \text { Were you surprised by anything in the } \\
\text { article? }\end{array}$ & & \\
\hline 02 & Explicit Correction & $\begin{array}{l}\text { The teacher } \\
\text { explicitly provides } \\
\text { the learners with the } \\
\text { correct form. }\end{array}$ & "That is not right, You should say ..." & & \\
\hline 03 & Repetition of Error & $\begin{array}{l}\text { The teacher repeats } \\
\text { the learner's error in } \\
\text { isolation, in most } \\
\text { cases, teachers } \\
\text { adjust their } \\
\text { intonation so as to } \\
\text { highlight the error. }\end{array}$ & $\begin{array}{l}\text { S: I going to visit my parents next week. } \\
\text { T: I going to...(emphasis) } \\
\text { S: I'm going to... }\end{array}$ & & \\
\hline 04 & Elicitation & $\begin{array}{l}\text { Teachers provide a } \\
\text { sentence and } \\
\text { strategically pause to } \\
\text { allow students to } \\
\text { "fill in the blank", }\end{array}$ & $\begin{array}{l}\mathrm{S}: \text { Androcles and the lion become good } \\
\text { friends. } \\
\mathrm{T}: \text { become? (emphasis) } \\
\mathrm{S}: \text { became }\end{array}$ & & \\
\hline 05 & $\begin{array}{l}\text { Metalingustic } \\
\text { Feedback }\end{array}$ & $\begin{array}{l}\text { The teacher } \\
\text { provides, } \\
\text { information, or } \\
\text { questions related to } \\
\text { an error the student } \\
\text { has made without } \\
\text { explicitly providing } \\
\text { the correct form. }\end{array}$ & $\begin{array}{l}\text { Students create a story with some } \\
\text { pictures. } \\
\text { S: When Androcles saw the lion he was... } \\
\text { T: surprise, surprised, surprising. } \\
\text { S: surprised }\end{array}$ & & \\
\hline 06 & $\begin{array}{l}\text { Clarification } \\
\text { Request }\end{array}$ & $\begin{array}{l}\text { The teacher asks for } \\
\text { repetition or } \\
\text { reformulation of } \\
\text { what the learner has } \\
\text { said. }\end{array}$ & $\begin{array}{l}\text { T: What's your surname? } \\
\text { S: Lucy } \\
\text { T: “pardon me”? What's your surname? } \\
\text { S: López. } \\
\text { T: Excellent! }\end{array}$ & & \\
\hline 07 & Denial & $\begin{array}{l}\text { The teacher tells the } \\
\text { learner that his/her } \\
\text { response was } \\
\text { incorrect and asks } \\
\text { him/her to say the } \\
\text { sentence without the } \\
\text { mistake. }\end{array}$ & "That's not correct, Could you try again". & & \\
\hline 08 & $\begin{array}{l}\text { Questioning (Peer } \\
\text { Correction) }\end{array}$ & $\begin{array}{l}\text { Learners correct to } \\
\text { each other in face- } \\
\text { to-face interaction in } \\
\text { a safe environment }\end{array}$ & $\begin{array}{l}\text { Learners work in pairs and read to each } \\
\text { other a tongue twister. } \\
\text { A student reads the line: A flea and a fly } \\
\text { flew up in a flue. She mispronounces the } \\
\text { word flew up. Her partner corrects her: A } \\
\text { flea and a fly [flu:] up in a flue. }\end{array}$ & & \\
\hline 09 & $\begin{array}{l}\text { Questioning (Self } \\
\text { Correction) }\end{array}$ & $\begin{array}{l}\text { Learners are aware } \\
\text { of mistakes they } \\
\text { make and repair } \\
\text { them. }\end{array}$ & $\begin{array}{l}\text { A Student answering to the question. } \\
\text { What did you do yesterday? "I go ... went } \\
\text { to the movies ..." }\end{array}$ & & \\
\hline 10 & Ignoring & $\begin{array}{l}\text { The student makes } \\
\text { an error and the } \\
\text { teacher does } \\
\text { nothing. }\end{array}$ & |---------------- & & \\
\hline
\end{tabular}

\section{Appendix (B). Types of Oral Corrective FeedBack Preferences Elicitation Instrument (Teachers)}

Dear colleague,

This questionnaire should take around 10 minutes to complete. Please answer ALL questions.

Thank you,

Part One: Personal Information: 
Please tick $(\sqrt{ })$ as appropriate:

Name:

School:
Grades you teach:
$\square 5-8$
$\square 9-10$
口11-12

Part Two: Oral Corrective Feedback Techniques:

The following is a short dialogue between a teacher and a student followed by several teacher responses. Imagine that one of your students had made the same mistake as the student in the following example. Rate how well you think each teacher response (1-10) helps the student understand that the teacher is trying to correct him.

$4=$ very helpful $3=$ helpful $2=$ moderately helpful $1=$ not helpful $0=$ not helpful at all

Example: Teacher: "Where have you been yesterday?" Student: "I has been to Nuscat."

\begin{tabular}{|c|c|c|c|c|c|c|c|c|}
\hline No & $\begin{array}{l}\text { Oral Corrective } \\
\text { Feedback Type }\end{array}$ & Definition & Teacher Response & 4 & 3 & 2 & 1 & $\mathbf{0}$ \\
\hline 01 & Recast & $\begin{array}{l}\text { The teacher repeats what the learner has said } \\
\text { replacing the error. }\end{array}$ & "'You have been to Muscat' & & & & & \\
\hline 02 & Explicit Correction & $\begin{array}{l}\text { The teacher explicitly provides the learners with } \\
\text { the correct form. }\end{array}$ & You should say 'have' not 'has' & & & & & \\
\hline 03 & Repetition of Error & $\begin{array}{l}\text { The teacher repeats the learner's error in isolation, } \\
\text { in most cases, teachers adjust their intonation so } \\
\text { as to highlight the error. }\end{array}$ & $\begin{array}{l}\text { "'I has been to Muscat'” stressing } \\
\text { 'has' }\end{array}$ & & & & & \\
\hline 04 & Elicitation & $\begin{array}{l}\text { Teachers provide a sentence and strategically } \\
\text { pause to allow students to "fill in the blank". }\end{array}$ & "I..." & & & & & \\
\hline 05 & Metalingustic Feedback & $\begin{array}{l}\text { The teacher provides, information, or questions } \\
\text { related to an error the student has made without } \\
\text { explicitly providing the correct form. }\end{array}$ & $\begin{array}{l}\text { "'You can't say 'has'. We use } \\
\text { 'have' with the pronoun I', }\end{array}$ & & & & & \\
\hline 06 & Clarification Request & $\begin{array}{l}\text { The teacher asks for repetition or reformulation of } \\
\text { what the learner has said. }\end{array}$ & "Do you mean...?" & & & & & \\
\hline 07 & Denial & $\begin{array}{l}\text { The teacher tells the learner that his/her response } \\
\text { was incorrect and asks him/her to say the sentence } \\
\text { without the mistake. }\end{array}$ & $\begin{array}{l}\text { "'That's not correct, could you try } \\
\text { again"' }\end{array}$ & & & & & \\
\hline 08 & $\begin{array}{l}\text { Questioning (Peer } \\
\text { Correction) }\end{array}$ & $\begin{array}{l}\text { Learners correct to each other in face-to-face } \\
\text { interaction in a safe environment }\end{array}$ & "'Is that correct?"' & & & & & \\
\hline 09 & $\begin{array}{l}\text { Questioning (Self } \\
\text { Correction) }\end{array}$ & $\begin{array}{l}\text { Learners are aware of mistakes they make and } \\
\text { repair them. }\end{array}$ & "'Is that correct, Ahmed?" & & & & & \\
\hline 10 & Ignorance & $\begin{array}{l}\text { The student makes an error and the teacher does } \\
\text { nothing. }\end{array}$ & ---------------- & & & & & \\
\hline
\end{tabular}

Thank you very much for your time and dedication.

APPENDIX (C). إستبانة لطلبة الصفوف (12 -

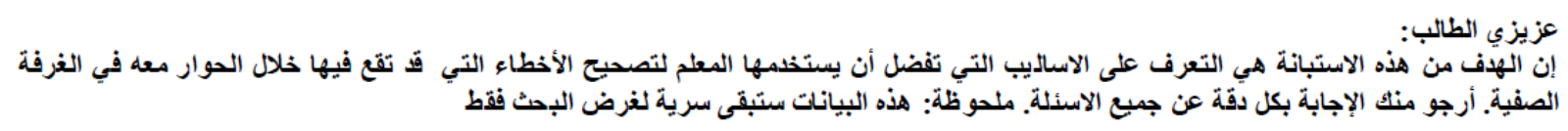

$$
\begin{aligned}
& \text { أولا: بيانات الطالب: } \\
& \text { أرجو وضع علامة (ل) ل على المربع الذي ينطبق عليك }
\end{aligned}
$$

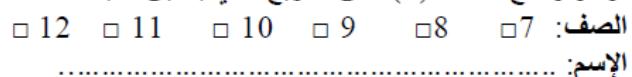

$$
\begin{aligned}
& \text { ثانيا: الاساليب المستخدمة في تصحيح الاخطاء: }
\end{aligned}
$$

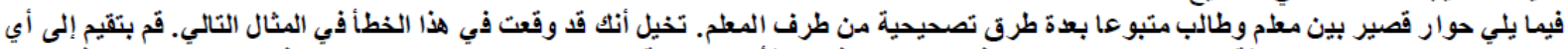

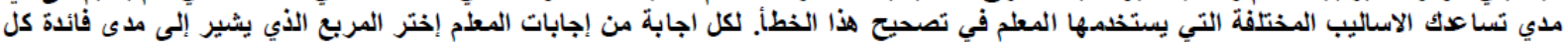





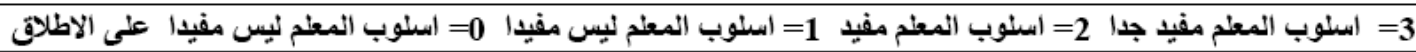

Example: What did you do yesterday?

I readed English. 


\begin{tabular}{|c|c|c|c|c|c|c|}
\hline No &  & 3 & 2 & 1 & $\mathbf{0}$ & 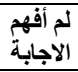 \\
\hline 01 & $\begin{array}{l}\text { English"- stressing “readed" "I readed } \\
\text { يكرر المعلم ما قلته حرفيا مع التشديد على مكان الخطأ }\end{array}$ & & & & & \\
\hline 02 & $\begin{array}{l}\text { يكرر المعلم ما قلته مع تصحيح الخط" "You read English" } \\
\text { " بكأ }\end{array}$ & & & & & \\
\hline 03 & $\begin{array}{l}\text { You يصحح المعلم مكان الخطأ تحديدا 'readed' no 'readed } \\
\text { should say 'read' }\end{array}$ & & & & & \\
\hline 04 & 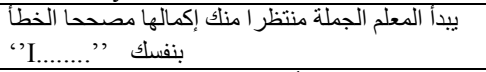 & & & & & \\
\hline 05 & "What?" " بسألك المعلم "ماذا؟؟ & & & & & \\
\hline 06 & 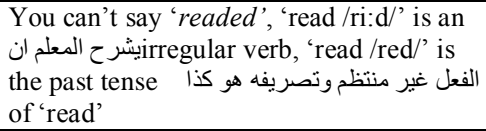 & & & & & \\
\hline 07 & $\begin{array}{l}\text { That is not correct, could you try again? } \\
\text { هذاولة أعير صحيح. فضلا المحلة }\end{array}$ & & & & & \\
\hline 08 & 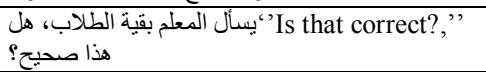 & & & & & \\
\hline 09 & 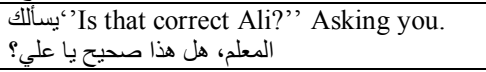 & & & & & \\
\hline 10 & $\begin{array}{l}\text { The teacher ignore your mistake } \\
\text { بتجاهل المعلم الاجابة الخاطئة }\end{array}$ & & & & & \\
\hline
\end{tabular}

\section{APPENDIX (D). FOLLOW- UP INSTRUMENT (TEACHERS)}

Dear colleague,

Hereby, we present you some of the results of our study and we would be very grateful if you could provide us with your comments about the possible reasons behind these results as well as any other remarks that you think will be useful for the study.

Thank you

Part One: Personal Information

Please tick $(\sqrt{ })$ as appropriate:

Name (optional):

School (optional):

Grades you teach: $\square 5-10$ $\square 11-12$

Part Two: Results of the Study

I. Recast, elicitation, and questioning (Peer-correction) were the most three used types of oral corrective feedback in $\mathrm{C} 2$ and $\mathrm{PB}$.

Comments:

-Teachers in $\mathrm{C} 2$ moderately used repetition, metalingustic feedback, clarification request, questioning (self-correction) and explicit correction and reported to have a very low usage of these in PB.

Comments:

Denial was reported to be of moderate use types of oral corrective feedback in PB, whereas it was reported to be very moderately used in $\mathrm{C} 2$.

Comments:

Teachers like metalingustic feedback, clarification request was reported of moderate use in $\mathrm{C} 2$ and of a very low frequency in PB.

Comments:

There is no significant relationship between English teachers' attitudes about oral corrective feedback and their actual practice.

Comments:

There were least cases in C2 where the students committed errors and their teachers did not provide them with any type of oral corrective feedback compared to $(\mathrm{PB})$. 
Comments:

Additional Notes:

\section{REFERENCES}

[1] Ancker, W. (2000). Errors and Corrective Feedback: Updated Theory and Classroom Practice. English Teaching Forum, 38 (4), 20-25.

[2] Basturkmen, H., Loewen, S., \& Ellis, R. (2004). Teachers' stated beliefs about incidental focus on form and their classroom practices. Applied Linguistics, 25(2), 243-272.

[3] Block, D. (1996). Window on the classroom: classroom events viewed from different angles, in Bailey \&Nunan: 168 - 194.

[4] Cathcart, R., \& Olsen J. (1976). Teachers' and students' preferences for correction of classroom conversation errors. TESOL, $76,41-45$.

[5] Chaudron, C. (1977). A descriptive model of discourse in the correctional treatment of learners' errors. Language Learning, 27, 29-46.

[6] Cohen, V. (1985). A reexamination of feedback in computer-based instruction: Implications for instructional design. Educational Technology, 25(1), 33-37.

[7] Doughty, C., \& Varela, E. (1998). Communicative focus on form. In C. Doughty \& J. Williams (Eds.), Focus on form in classroom second language acquisition (pp. 114-138). New York: Cambridge University Press.

[8] El Tatawy, M. (2002). Corrective feedback in second language acquisition. Teachers' College, Columbia University, 1-19.

[9] Ellis, R. (1993). Second language acquisition and the structural syllabus. TESOL Quarterly, 27, 91-113.

[10] Ellis, R. (1999). Learning a second language through interaction. Amsterdam: John Benjamins Publishing Company.

[11] Karavas-Doukas, E. (1996). Using attitude scales to investigate teachers' attitudes to the communicative approach. English Language Teaching Journal, 50(3), 187-198.

[12] Kartchava, E. (2006). Corrective Feedback: Novice ESL Teachers' Beliefs and Practices. A Thesis in the Department of Education TESL Centre. In (Applied Linguistics) at Concordia University, Montreal, Quebec, Canada. March (2006), 1-125.

[13] Katayama, A. (2006). Perceptions of JFL students toward correction of oral errors. In Bradford-Watts, K., Ikeguchi, C., \& Swanson, M. (Eds.) JALT2005 Conference Proceedings, Tokyo: JALT, 1248-1264.

[14] Lin, H. (2009). Patterns of Corrective Feedback and Learner Uptake in ESL Low, Intermediate, and Advanced Level Speaking Classrooms (PHD Dissertation). Alliant International University, San Diego.

[15] Loewen, S. (2004). Uptake in Incidental Focus on form in Meaning-Focused ESL Lessons. Language Learning, 54 (1), $153-$ 188.

[16] Long, M. (1977). Teacher feedback on learner error: mapping cognitions. In Brown, H. D., Yorio, C. A., \& Crymes, R. (eds.), On TESOL '77. Teaching and learning English as a Second Language: Trends in research and practice, 278-294.

[17] Long, M. (1996). The role of the linguistic environment in second language acquisition. In Ritchie, W. \& Bhatia, T. (eds.), Handbook of Research on Language Acquisition, 413-468. San Diego: Academic Press.

[18] Lyster, R. \& Ranta, L. (1997). Corrective feedback and learner uptake: Negotiation of form in communicative classrooms. Studies in Second Language Acquisition. 19, 37-66.

[19] Lyster, R. (1998a). From immersion classroom discourse: In or out of focus? Canadian Journal of applied Linguistics, 1(1-2), 53-82.

[20] McCargar, D. (1993). Teacher and student role expectations: Cross-cultural differences and implications. The Modern Language Journal, 77(2), 192-207.

[21] Nunan, D. (1987). Communicative language teaching: The learner's view. In Bikram, K. (Ed.), Communication and learning in the classroom community, (pp. 176-190). Singapore: SEAMEO Regional Language Centre.

[22] Nunan, D. (1988). The learner- centered curriculum. Cambridge: Cambridge University Press.

[23] Nunan, D. (1991). Language Teaching Methodology: A text for teachers. London. Prentice Hall International.

[24] Oladejo, J. (1993). Error correction in ESL: Learners' preference. TESL Canada Journal, 10(2), 71-89.

[25] Panova, I. \& Lyster, R. (2002). Patterns of corrective feedback and uptake in an adult ESL classroom. TESOL Quarterly, 36(4), 573-595.

[26] Pica, T. \& Long, M. (1986). The Classroom and linguistic performance of experience and inexperienced ESL teacher." In Day, R. (Ed.) Talking To Learn (PP.85-98), P.96. Rowley, MA: Newbury House.

[27] Roskams, T. (1999). "Chinese Efl Students' Attitudes to Peer Feedback and Peer Assessment in an Extended Pairwork Setting". RELC Journal, 30, 79- 123.

[28] Rudduck, J. (1991). Innovation and change. Milton Keynes, England: Open University Press.

[29] Russell, J. \&Spada, N. (2006). The effectiveness of corrective feedback for the acquisition of grammar: A meta-analysis of research .Amsterdam. John Benjamins Publishing.

[30] Schulz, R. (1996). Focus on form in the foreign language classroom: students' and teachers' views on error correction and the role of grammar. Foreign Language Annals, 29 (3), 343-364.

[31] Sengupta, S. (1998). "Peer Evaluation" "I am not the teacher". ELT Journal, 52(1), 19- 28.

[32] Sheen, Y. (2004). Corrective feedback and learner uptake in communicative classrooms across instructional settings. Language Teaching Research, 8, 263-300.

[33] Sinclair, J. \& Brazil, D. (1982). Teacher Talk. Oxford: Oxford University Press.

[34] Smith, H. (2010). Correct Me if I'm Wrong: Investigating the Preferences in Error Correction Among Adult English Language Learners. (MA thesis 2010). University of Central Florida Orlando, Florida. 
[35] Smith, P., \& Ragan, T. (1993). Designing instructional feedback for different learning outcomes. In Dempsey, J \& Sales, G (Eds.), Interactive instruction and feedback (pp. 75-103). Englewood Cliffs, NJ: Educational Technology.

[36] Tabatabaei, O. \& Banitalebi, A. (2011). Feedback Strategies in Foreign Language Reading Classes. Asian Culture and History, $3(2), 59-70$

[37] The Sultanate of Oman. Ministry of Education. (2011). The English Language Curriculum Framework. Directorate General of Curriculum Development.

[38] The Sultanate of Oman. Ministry of Education. (2004). National Report on Quality Education in Oman. Retrieved from: http://www.ibe.unesco.org/International/ICE47/English/Natreps/reports/oman_part_1.pdf.

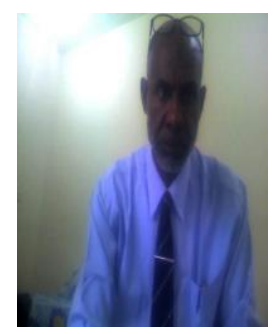

Ibrahim Mohamed Al-Faki is an Associate Professor of English Applied Linguistics. He was born in Omdurman, Sudan, 1957. He got his B.Ed. in (1986) in English language and Literature from the University of Juba, South Sudan and his M.Ed. in (1993) from the University College of Dublin in Ireland. Mr. Al-Faki got his Ph.D in ELT from the Nile Valley University in (2000) in Sudan. Dr Al-Faki has been teaching English since 1978 at the general Education in the Sudan as well as teaching at tertiary levels. He also has been supervising M.A and Ph.D theses since 2005. He is an active remember in the Association of Sudanese Teachers of English \& the Association of Professors of English and Translation at Arab Universities. He has written more than 7 textbooks as basic references in English teaching in Sudanese Universities. Dr. Al-Faki is on secondment now as English Language lecturer in ELI in King A/Aziz University in Jeddah in KSA.

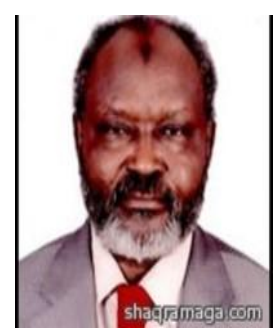

Ahmed Gumaa Siddiek, got his B.A in English with (MERIT) from Khartoum University in (1982). He has an MA in Translation from the Islamic Institute for Translation in Khartoum as well as an M.Ed in (TEFL) from Juba University - Sudan (2002). Mr Siddiek got his Ph.D with (EXCELLENT) in (Language Testing)) in (2004) from Omdurman Islamic University - Sudan. Since then, Dr. Siddiek has been lecturing in Sudan and Saudi Arabia. He has published articles in ELT journals in USA, UK, Canada, Finland and Australia. He attended conferences and read papers in Harvard, Purdue, Ohio State University in the USA, Germany, France \& Canada. Dr. Siddiek is the Author of: (Assessment of the Sudan School Certificate English Examinations) \& (Language Challenges in Post-War Sudan). Both books are available at amazon.net. Dr.Siddiek is a member of editorial Boards of (International Journal of English Linguistic, English Language and Literature Studies- in Canada, and he is an Associate Editor in (International Journal of Applied Linguistics \& English Literature - Australia). 